\title{
In Vitro Study of Antioxidant and Antimicrobial Activities of Garcinia mangostana L. Peel Extract
}

\author{
Anastasia Wheni Indrianingsih ${ }^{1, *}$, Vita Taufika Rosyida ${ }^{1}$, Dwi Ratih ${ }^{1}$, Batrisya ${ }^{2}$ \\ ${ }^{1}$ Research Division for Natural Product Technology, Indonesian Institute of Science, Yogyakarta, Indonesia \\ ${ }^{2}$ Department Chemistry, Universitas Negeri Yogyakarta, Yogyakarta, Indonesia \\ *Corresponding author. Email: anastasia.wheni.i@gmail.com
}

\begin{abstract}
Plant extract are natural additives that are in great demand. Many biological capabilities of plant extracts in the fields of health and medicine, make research on plant extract quite rapid. Mangosteen (Garcinia mangostana L.) is one of the most famous fruits in Indonesia. In this paper, the antimicrobial and antioxidant activities of mangosteen peel were studied. The mangosteen peel extract were prepared by maceration method using ethanol for 48 hours. After the evaporation, the crude extracts were tested using DPPH assay for antioxidant activity and antibacterial activity was performed using dilution method. The scavenging activity of mangosteen peel extracts values in the range of $73.57-79.14 \%$ with extract concentration of $100 \mathrm{ppm}$ to $800 \mathrm{ppm}$, respectively. The antibacterial activity of mangosteen peel extract were conducted against Gram-positive bacteria (S. aureus) and Gram-negative bacteria (E. coli). The inhibition zone of mangosteen peel extract was $6.95 \mathrm{~mm}$ against $S$. aureus and $5.33 \mathrm{ppm}$ against $E$. coli at extract concentration of $10000 \mathrm{ppm}$. The results obtained indicate that mangosteen peel extract is potentially applied in the fields of medicine and health.
\end{abstract}

Keywords: mangosteen, antioxidant, antibacterial, DPPH assay

\section{INTRODUCTION}

Plants extracs including herbs and spices have consisted of natural compounds, that usually used in food ingredients. Besides to improve the taste and flavor of food, it also possessed natural antioxidant and antimicrobial properties. Recently, the antioxidant and antimicrobial from plants is preferred compared to synthetic antioxidant, since there are several of negative effect of synthetic antioxidant. According to consumers, more fresh and natural foods with fewer synthetic additive are important [1]. Because of this, the plants have a tendency of replacing synthetic antioxidants and antimicrobial agents [2]. The utilization of plants extracts as antioxidant and antimicrobial agents are urgently needed to reduce the health hazard and to prolong the shelflife of food.

Mangosteen (Garcinia mangostana L.) is one of the famous fruits in Indonesia. Some studies have shown that the extracts from mangosteen parts (barks, leaves, peel) contain bioactive compounds such as xanthones [3]. Xanthones from G. mangostana possess several activity such as antifungal, antibacterial, antiviral, anti-inflammatory dan antiallergy [4,5]. The aim of this present study is to evaluate the antioxidant and antibacterial activity of G. mangostana peel extract from Sleman district, Yogyakarta Province, Indonesia.

\section{METHODS}

\section{A. Preparation of G. mangostana extract}

The mangosteen peel (G. mangostana) was collected from Sleman, Yogyakarta, Indonesia on January 2019. The $G$. mangostana peels were first cleaned and washed thoroughly to remove any impurities. After washing, the peel was chopped into small pieces. The samples were dried using usual drying under sunlight (without direct exposure) for 3 days. The dried samples were ground to be powder and macerated in ethanol $95 \%(1: 6 \mathrm{w} / \mathrm{v})$ for 2 days at room temperature. After filtration and evaporation of the filtrate, the ethanolic extract of $G$. mangostana was obtained.

\section{B. FTIR spectroscopy characterization}

The FTIR characterization of $G$. mangostana peel was performed using FTIR spectrometer Shimadzu 8201 PC (Japan). The samples were mixed with $\mathrm{KBr}$ and the FTIR spectra were evaluated in the range of 4000 to $500 \mathrm{~cm}^{-1}$.

\section{DPPH scavenging activity assay}

The antioxidant activity of $G$. mangostana peel extract was performed by DPPH method according to Darsih et al. (2019) with light modification [6]. Several concentrations of $G$. mangostana ethanolic extracts were dissolved in methanol, and then reacted with DPPH $1.01 \mathrm{mM}$ at dark room temperature for 30 minutes. The absorbance was recorded using Elisa Reader at $517 \mathrm{~nm}$. The scavenging activity was calculated by the equation as follows: 
DPPH radical scavenging activity $(\%)=\left(\frac{A_{o}-A_{1}}{A_{o}} \times 100\right)$ (1) where $A_{o}$ is absorbance of the control and $A_{1}$ is absorbance of the sample. The assays were carried out in triplicates. Ascorbic acid was used as positive control.

\section{Antibacterial activity assay}

The antibacterial activity of the $G$. mangostana peel extract was evaluated against $E$. coli and $S$. aureus using agar well diffusion method [7]. The G. mangostana peel extract was dissolved in DMSO. Approximately $100 \mu \mathrm{L}$ of bacteria suspension were inoculated in nutrient agar plates. The wells were punched in the solid media. Several concentrations of the G. mangostana ethanolic extracts were added to wells, and then incubated at $37{ }^{\circ} \mathrm{C}$ for 24 hours. Ampicillin was used as a positive control, while DMSO was used as a negative control. The antibacterial activity was evaluated by measuring the inhibition zone diameter after incubation.

\section{RESULTS AND DISCUSSION}

In this study, G. mangostana peel extract was obtained by maceration process using ethanol. Ussually, extraction of $G$. mangostana with ethanol resulting in several active compound such xanthone and other phenolic compounds $[8,9]$. The result of $G$. mangostana peel extraction showed that the yield of as of $9.75 \%(\mathrm{w} / \mathrm{w})$.

The antioxidant activity of $G$. mangostana peel extract was evaluated using DPPH radical scavenging assay. This method is the most extensively used to perform the radical scavenging activity of plant extracts. The antioxidant of $G$. mangostana peel extract can be seen in Figure 1.

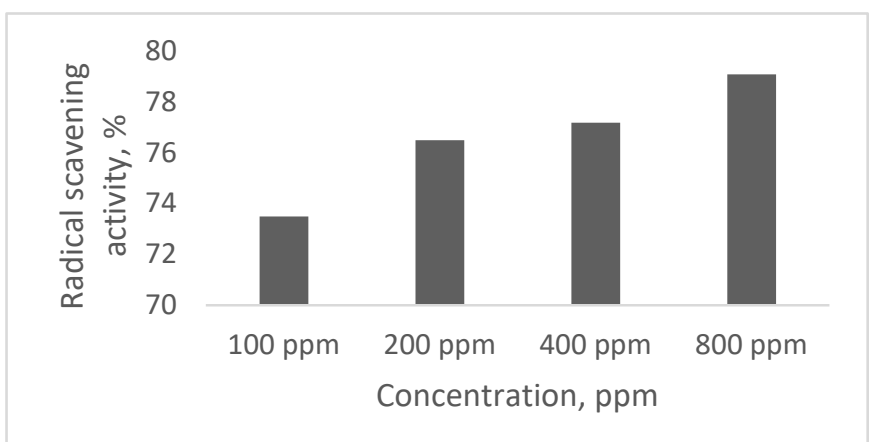

Figure 1. Radical scavenging activity of $G$. mangostana peel extract.

Based on the DPPH assay, the higher the concentration of $G$. mangostana peel extract, the higher the radical scavenging activity. The $G$. mangostana peel extract has high activity as of $73.6 \%$ at $100 \mathrm{ppm}, 76.5 \%$ at $200 \mathrm{ppm}, 77.2 \%$ at $400 \mathrm{ppm}$ and $79.1 \%$ at $800 \mathrm{ppm}$. The IC 50 of G. mangostana peel extract is below $50 \mathrm{ppm}$, meanwhile ascorbic acid as a positive control has a radical scavenging activity as of 76.7 at $25 \mathrm{ppm}$.

Several studies had evaluated the potential of antioxidant activity of $G$. mangostana. Research by Palakawong et al., 2010 showed that extract of G. mangostana peel using ethanol $50 \%$ had the highest radical scavenging activity
(IC50 $=5.94 \mu \mathrm{g} / \mathrm{ml})$ compared to bark and leaves (IC50 = 6.46 and $9.44 \mu \mathrm{g} / \mathrm{ml}$, respectively). A study by Zadernowski et al. (2009) [10] reported that peel of mangosteen (inner peel and outer peel) rich of phenolic contents. Moreover, some research showed that antioxidant activity was in correlation with its phenolic content $[11,12]$. The different extraction method of $G$. mangostana and the maturity level of $G$. mangostana also can result in different results of its antioxidant activity $[12,13,14]$.

In this study, agar well diffusion method is used to evaluate the antibacterial activity of G. mangostana peel extract. The inhibition zone area is the parameter of the antibacterial activity. G mangostana peel extract was assessed for the antibacterial activity against $E$. Coli as a gram-negative bacteria and $S$. aureus as a gram-positive bacteria. The positive control was using ampicilin, while the negative control was using DMSO. The results are presented in Table 1.

Table 1. Antibacterial activity of $G$. mangostana peel extract against $E$. coli and $S$. aureus

\begin{tabular}{ccccc}
\hline Bacteria & $\begin{array}{c}\text { Concentration } \\
\text { of } G .\end{array}$ & \multicolumn{3}{c}{$\begin{array}{c}\text { Inhibition zone diameter } \\
(\mathrm{mm})\end{array}$} \\
\cline { 3 - 5 } & $\begin{array}{c}\text { mangostana } \\
\text { extract }(\mathrm{ppm})\end{array}$ & well 1 & well 2 & Mean \\
\hline E. coli & 500 & 2.95 & 2.65 & 2.80 \\
& 1000 & 5.75 & 5.66 & 5.70 \\
S. aureus & 10000 & 4.32 & 4.84 & 4.58 \\
& 500 & - & - & - \\
Ampicillin & 1000 & - & - & - \\
DMSO & 10000 & 7.27 & 6.58 & 6.92 \\
\hline
\end{tabular}

At the concentration of $500 \mathrm{ppm}$, G. mangostana peel extract showed inhibition activity of bacterial growth as of $2.80 \mathrm{~mm}$ against $E$. coli but no inhibition against $S$. aureus. At concentration $1000 \mathrm{ppm}, G$. mangostana peel extract inhibited $E$. coli growth with inhibition zone diameter as of $5.70 \mathrm{~mm}$, while it was no inhibition against $\mathrm{S}$. aureus. However, G. mangostana peel extract showed good inhibition against $S$. aureus at $10000 \mathrm{ppm}$ as of $6.92 \mathrm{~mm}$, while against $E$. coli as of $4.58 \mathrm{~mm}$. DMSO that used as solvent showed no inhibition against the bacteria, while ampicillin as positive control showed inhibition as of 27.8 $\mathrm{mm}$.

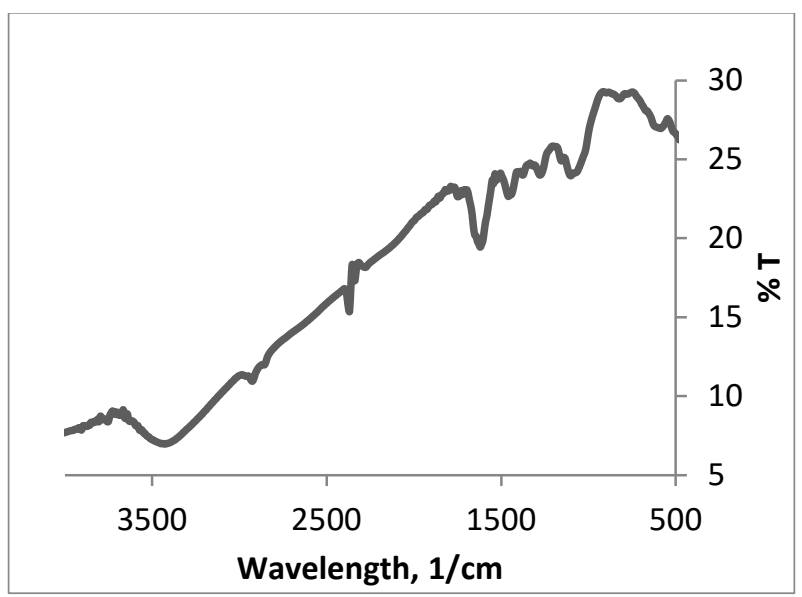

Figure 2. FTIR spectra of G. mangostana peel 
The study by Palakawong et al., 2010 [15] also showed that the extract of $G$. mangostana extracts (peel, barks and leaves) had a strong antibacterial activity against gram-positive bacteria. Several studies found that in the mangosteen, especially the peel part, there were xanthone, an active compound that can inhibit microorganism. Bioactive compounds of $\alpha$ - and $\beta$-mangostin were found in mangosteen $[8,9]$. Study by Sakagami et al (2005) [16] and Iinuma et al (1996) [17] also reported that $\alpha$ - and $\beta$-mangosteen had antibacterial activity against $S$. aureus. According to this study and literature, it can be indicated that the antibacterial activity against $S$. aureus and $E$. coli of the $G$. mangostana peel extracts possibly comes from xanthone and phenolic compounds in G. mangostana peel extracts.

The functional groups of compounds in G. mangostana peel were analyzed using FTIR spectroscopy. The FTIR spectra of G. mangostana peel extracts were recorded in the range of 4000 to $500 \mathrm{~cm}^{-1}$ and presented in Figure 2 and Table 2 .

Table 2. Interpretation of functional groups of $G$. mangostana peel by FTIR spectroscopy

\begin{tabular}{ccc}
\hline Functional group vibration & Wavenumber $\left(\mathrm{cm}^{-1}\right)$ & Intensity \\
\hline O-H, alcohols, phenol & 3425,58 & broad \\
C-H, alkane & $2862,36-2924,09$ & sharp \\
C=C, alkene & 1620,21 & sharp \\
C=C, aromatics & 1520 & sharp \\
C-C, aromatics & 1442 & sharp \\
C-O, aldehyde, caraboxcylic acid, ester & 1705 & sharp \\
\hline
\end{tabular}

The prominent and broad band at $3425 \mathrm{~cm}^{-1}$ corresponded to $\mathrm{O}-\mathrm{H}$ stretch with $\mathrm{H}$-bonded, indicating the existence of phenols compounds in the G. mangostana peel. This existence of phenol also indicated by the vibration band around $1520 \mathrm{~cm}^{-1}$ that possibly is from $\mathrm{C}=\mathrm{C}$ vibration of aromatics. The absorption bands around $2924 \mathrm{~cm}^{-1}$ and 1050 $\mathrm{cm}^{-1}$ indicated the peak of carboxylic acid groups. From this FTIR spectra, it can be concluded that $G$. mangostana peel possibly had polyphenol and flavonoid compounds. This result was also in accordance with literatures [18]. The antibacterial and the antioxidant of G. mangostana is possibly contributed from polyphenol and flavonoid compounds.

\section{CONCLUSION}

In conclusion, G. mangostana collected from Sleman, Yogyakarta, Indonesia exhibit good antioxidant and antibacterial activity. G. mangostana peel extract showed good antibacterial activity against $E$. coli at lower concentration compared to $S$. aureus. The antioxidant activity of $G$. mangostana peel extract was higher than that of ascorbic acid as positive control. It is likely that the antioxidant and antibacterial activity was attributed to the phenolic and flavonoid compounds of G. mangostana peel extract.

\section{ACKNOWLEDGMENT}

Thank you to Ms. Nurina Indirayati for technical support assistance during the research.

\section{REFERENCES}

[1] P.S. Negi, G.K. Jayaprakasha and B.S. Jena. "Antibacterial activity of the extracts from the fruit rinds of Garcinia cowa and Garcinia pedunculata against food borne pathogens and spoilage bacteria". LWT - Food Sci. Technol. vol 41, pp. 1857-1861, 2008.

[2] P. Mayachiew and S. Devahastin. "Antimicrobial and antioxidant activities of Indian gooseberry and galangal extracts". LWT - Food Sci. Technol. vol. 41, pp. 1153-1159, 2008.

[3] V. Peres, T.J. Nagem and F.F. de Oliveira. "Tetraoxygenated naturally occurring xanthones". Phytochem. vol 55, pp. 683-710, 2000.

[4] S. Suksamrarn, O. Komutiban, P. Ratananukul, N. Chimnoi, N. Lartpornmatulee and A. Suksamrarn. "Cytotoxic prenylated xanthones from the young fruit of Garcinia mangostana". Chem. Pharma. Bull. vol. 54, pp. 301-305, 2006.

[5] J. Pedraza-Chaverri, N. Cardenas-Rodriguez, M. Orozcolbarra and J.M. Perez-Rojas. "Medicinal properties of mangosteen (Garcinia mangostana)". Food Chem. Toxicol. vol. 46, pp. 3227-3239, 2008.

[6] C. Darsih, A.W. Indrianingsih, W. Apriyana, S.N. Hayati ,V.T. Rosyida, K. Nisa, D. Ratih and N. Indirayati. "Antioxidant activity of methanol extracts from Ganoderma lucidum Karst mycelia". IOP Conf. Ser.: Earth Environ. Sci. vol. 251, pp. 012015, 2019.

[7] P. Dahiya and S. Purkayastha. "Phytochemical screening and antimicrobial activity of some medicinal plants against multi-drug resistant bacteria from clinical isolates". Indian J. Pharm. Sci. vol. 74(5). pp. 443-450, 2012.

[8] K. I. Furukawa, K. Shibusawa, N. Chairungsrilerd, T. Ohta, S. Nozoe and Y. Ohizumi. "The Mode of Inhibitory Action of $\alpha$ Mangostin, a Novel Inhibitor, on the Sarcoplasmic Reticulum Ca2+-Pumping ATPase from Rabbit Skeletal Muscle". Japan J Pharm. vol. 71, pp. 337-340, 1996.

[9] L.G. Chen, L.L. Yang and C.C. Wang 2008. "Antiinflammatory activity of mangostins from 
Garcinia mangostana”. Food Chem. Toxicol. vol. 46. pp. 688693, 2008.

[10] R. Zadernowski, S. Czaplicki and M. Naczk. "Phenolic acid profiles of mangosteen fruits (Garcinia mangostana)". Food Chem. vol. 112, pp. 685-689, 2009.

[11] P. Maisuthisakul, S. Pasuk and P. Ritthiruangdej. "Relationship between antioxidant properties and chemical composition of some Thai plants". J Food Comp. Anal. vol. 21. pp. 229-240, 2008.

[12] X. Liu, M. Zhao, J. Wang, B. Yang and Y. Jiang. 2008. "Antioxidant activity of methanolic extract of emblica fruit (Phyllanthus emblica L.) from six regions in China". J Food Comp. Anal. vol. 21, pp. 219-228, 2008.

[13] S. Okonogi, C. Duangrat, S. Anuchpreeda, S. Tachakittirungrod and S. Chowwanapoonpohn. "Comparison of antioxidant capacities and cytotoxicities of certain fruit peels". Food Chem. vol. 103, pp. 839-846, 2007.

[14] W. Suttirak and S. Manurakchinakorn. "In vitro antioxidant properties of mangosteen peel extract". J Food Sci Technol. vol. 51(12), pp. 3546-3558, 2014.
[15] C. Palakawong, P. Sophanodora, S. Pisuchpen and S. Phongpaichit. "Antioxidant and antimicrobial activities of crude extracts from mangosteen (Garcinia mangostana L.) parts and some essential oils". Inter. Food Res. J. vol. 17. pp. 583-589, 2010.

[16] Y. Sakagami, M. Iinuma, K.G.N.P. Piyasena and H.R.W. Dharmaratne 2005. "Antibacterial activity of $\alpha$-mangostin against vancomycin resistant Enterococci (VRE) and synergism with antibiotics". Phytomed. vol. 12, pp. 203-208, 2005.

[17] M. Iinuma, H. Tosa, T. Tanaka, F. Asai, Y. Kobayashi, , R. Shimano and K. Miyauchi. "Antibacterial activity of xanthones from guttiferaeous plants against methicillin-resistant Staphylococcus aureus". J Pharm. Pharmacol. vol. 48, pp. 861-865, 1996.

[18] N.A. Mahir and H. Ismail. "Study of mangosteen (garcinia mangostana) peel powder as antioxidant in natural rubber compound". $J$ Vinil Add Technol. vol. 2015. pp. 1-7, 2015. 